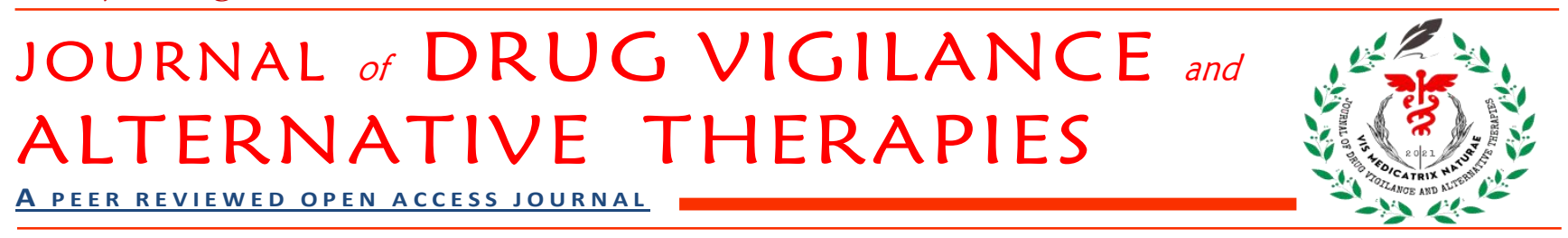

J Drug Vigil Altern Ther. 2021; 1(1):29-36

doi: 10.52816/JDVAT.2021.1105

\title{
Isolation and Characterization of Probiotics from Different Curd Samples
}

\author{
Kammari Shirisha ${ }^{1}$, J. P. Priyanka ${ }^{1}$, B. Lakshmi Satya ${ }^{* 2}$ \\ ${ }^{1}$ Department of Biotechnology, Vishnu Institute of Pharmaceutical Education \& Research, JNTU Hyderabad \\ University, Medak, Telangana, India - 502313. \\ ${ }^{*}$ Assistant Professor, Department of Biotechnology, Vishnu Institute of Pharmaceutical Education \& \\ Research, JNTU Hyderabad University, Medak, Telangana, India - 502313.
}

\section{ABSTRACT}

Probiotics are living micro-organisms which have a positive impact on the survival of their hosts. Curd's nutrient properties have long piqued the medical community's attention. Curd has been a popular milk based commodity in India since the dawn of time. Lactic acid bacteria were derived from different curd samples and their probiotic ability was studied in this research. On the basis of the catalase assay and gram staining, a total of 8 lactic acid bacteria were isolated. Many of the isolates tested positive for gram and negative for catalase. They all had a lot of probiotic promise. Both species were shown to be immune to low $\mathrm{pH}(\mathrm{pH} 3)$ and concentrations of 0.3 percent bile salts. They were shown to have antibacterial action toward three laboratory species with high antibiotic tolerance.

Keywords: Probiotics, curd, lactic acid bacteria, bile salts, antibacterial activity, antibiotic resistance.

\section{INTRODUCTION}

Probiotics are living microorganisms (mostly bacteria) that are identical to the bacteria of the human gut. Probiotics are also known as beneficial bacteria or healthy bacteria. ${ }^{1}$ People will get them in the form of food additives and products. Probiotics are bacteria that are comparable to those produced naturally in people's guts. They can be used as complementary and alternative medicine (CAM). ${ }^{2}$ According to the World Health Organization and the Food and Agriculture Organization of the United Nations, probiotics are 'microbes that, if administered in adequate amounts, impart a health benefit on the host'. ${ }^{3}$ Probiotics are bacteria that are identical to those found naturally in people's guts, especially in breastfed infants' guts. Some traditional probiotics, like Saccharomyces boulardii, are yeasts rather than bacteria. Fermented foods and cultured milk products are examples of probiotic foods that date back to ancient times. ${ }^{4}$

Probiotics are common for a number of reasons. Interactions between a human and the microorganisms in his body, as well as interactions within microorganisms, may be critical to a person's health and well-being. Some people take probiotics that help with antibiotic side effects like discomfort, stomach cramps, vomiting and diarrhea. Similarly, some people use them to help with lactose sensitivity symptoms. ${ }^{5}$

Lactic acid bacteria (LAB) are gram-positive, rod-shaped, non-motile bacteria that can be found

*Corresponding Author: satyabio@gmail.com

Received: 10 Febraury 2021

Revised: 1 March 2021

Accepted: 5 March 2021

(C)2020. Open access. This article is distributed under the terms of the Creative Commons Attribution-Noncommercial-Share Alike 4.0 Unported License. 
in fruit, soil, water, and plants. They are naturally found in the gastrointestinal and respiratory tracts of humans and animals. They can usually thrive in both aerobic and anaerobic conditions. They feed on lactose and contain lactic acid as a byproduct in milk, that lowers the $\mathrm{pH}$ and denatures or ferments the casein protein. ${ }^{6}$ While LAB are commonly used as a starter culture in the food industry for the production of fermented foods such as dairy, meat, fish, cereals, fruit, and vegetables, they are also commonly found in nonfermented foods and are considered safe by the US Food and Drug Administration (FDA). ${ }^{7}$

Obtaining new probiotic bacteria strains from rare and novel conventional food sources with satisfactory practical, technical, and medicinal potential is currently a major focus in the food and pharmaceutical industries. ${ }^{8}$ Additionally, there's been an increase in global demand in the use of functional foods/nutraceuticals containing possible probiotic microorganisms, with an international market worth more than US \$28.8 billion. Food science and technological advancements are supplying the food industry with more efficient methods to monitor and enhance the nutritional characteristics and structure of food items, allowing for the development of functional foods with probiotics that have benefits above nutritive value. ${ }^{9,10}$

Lactobacilli play a significant role in gut microflora regulation and can help deter pathogenic bacteria from growing by developing antimicrobial compounds. They are grown naturally in foods and can be used as biological preservatives. Owing to a drop in $\mathrm{pH}$, demand for substrates, and the production of antimicrobial compounds such as lactic acid, acetic acid, hydrogen peroxide, and carbon dioxide in addition to bacteriocins, LAB has a wide range of inhibitory activity. Lactic acid bacterial species with reported health benefits, such as Lactobacillus rhamnosus, Lactobacillus casei, and Lactobacillus johnsonii were developed as probiotics in the past years. . ${ }^{11,12}$

The objective of this research was to see whether isolated lactobacilli from various curd samples had an antagonistic effect against three standard strains of Staphylococcus aureus, Pseudomonas aeruginosa, and Escherichia coli.

\section{MATERIAL AND METHODS}

Five different curd samples were obtained from local source of Hyderabad, Telangana. Biochemical tests were used to identify strains of Lactobacillus cultures. MRS Agar (Sigma Aldrich, Hyderabad) was used to isolate Lactobacillus cultures. Gram stain, catalase, ammonia development, growth at various temperatures $\left(15-37-45^{\circ} \mathrm{C}\right)$ and various sugar fermentations were all investigated.

\subsection{Isolation of Lactic Acid Bacteria (LAB)}

Lactic acid bacteria are derived from curd obtained from various dairy products sources. Specimens were tested in sterile ice bottles and held in an icebox until they were sent to the lab for examination. The curd samples were submerged and dissolved in sterile saline before being spread plated into selective medium (MRS) and incubated anaerobically for 24 hours at $37^{\circ} \mathrm{C}$. Using the streak plate procedure, the picked colonies were purified. The purified bacterial strains were held at $-80^{\circ} \mathrm{C}$ in sterile reconstituted skim milk supplemented with $15 \%$ glycerol and stored at $-80^{\circ} \mathrm{C}$.

\subsection{Gram Staining and Motility}

Using a gram staining kit, the isolated bacteria were analyzed under a compound microscope at magnifications of $10 \mathrm{x}, 45 \mathrm{x}$, and 100x. Motility testing was done using the hanging-drop wet process. To check the bacteria's locomotion, the slides were examined under a light microscope at $45 \mathrm{x}$ magnification. ${ }^{13}$

\subsection{Physiological and Biochemical Characterization}

\subsubsection{Growth at Various Temperatures}

Pure colonies grown on MRS agar were inoculated into tubes containing MRS broth and incubated at $15^{\circ} \mathrm{C}, 30^{\circ} \mathrm{C}$, and $45^{\circ} \mathrm{C}$ for 24 hours in anaerobic jars. If turbidity was detected after 24 hours, the results were considered positive. ${ }^{13,14}$

\subsubsection{Gas Production from Glucose}

A modified MRS broth was prepared for this examination, with ammonium sulfate replacing 
ammonium citrate. The solution was then pumped into Durham tube-containing tubes and sterilized. The pure colonies were then cultivated on agar inoculated in this medium and incubated in anaerobic jars at $35^{\circ} \mathrm{C}$ for 3 days. The outcome was considered positive if $\mathrm{CO}_{2}$ was derived from the fermented glucose. ${ }^{14}$

\subsubsection{Arginine Hydrolysis Test}

For this experiment, a foundation MRS broth medium was made without beef extract but with 0.3 percent arginine and 0.2 percent ammonium citrate. The colonies from the basal medium then were inoculated into the prepared medium and incubated at $35^{\circ} \mathrm{C}$ for 72 hours in anaerobic barrels. Nessler's reagent $\left(\mathrm{K}_{2} \mathrm{HgI}_{4}\right)$ was used to continue the research. ${ }^{15}$

\subsubsection{Carbohydrate Fermentation}

The Marroki (2011) process was used to assess sugar fermentation using eight separate sugars (mellibiose, cellobiose, lactose, sucrose, raffinose, gluconate, salicine, and arabinose). ${ }^{16}$

\subsubsection{Catalase Test}

A single isolated colony was streaked on a glass slide and a drop of 3 percent hydrogen peroxide was introduced to it to carry out the test. The exuberance of oxygen implied that the bacteria had responded positively to the catalase test. ${ }^{17}$

\subsubsection{Salt Intolerance Test}

Salt tolerance was measured in MRS broth by adding 2, 4, and 6.5 percent sodium chloride $(\mathrm{w} / \mathrm{v})$ and incubating at $37^{\circ} \mathrm{C}$ according to Menconi's (2014) process. ${ }^{13}$

\subsection{Resistance to Low $\mathrm{pH}$}

The tolerance to bile was determined using a 0.3 percent $(\mathrm{w} / \mathrm{v})$ intestinal bile concentration and a 4 hour food stay period in the small intestine. MRS medium with a bile concentration of 0.3 percent $(\mathrm{w} / \mathrm{v})$ was inoculated with a lactic acid bacteria culture overnight. On MRS agar, viable colonies were counted every hour of incubation time, and development was tracked at $\mathrm{OD}_{620}{ }^{13,19,20}$

\subsection{Antimicrobial Activity}

The disc diffusion process, as defined by Hassanzadazar et al. (2012) was used to evaluate the antimicrobial activity of the lactic acid bacteria isolates. Nutrient Agar $(20 \mathrm{~mL})$ was poured onto the dishes. On the surface of nutrient agar, pathogenic strains (Staphylococcus aureus, Pseudomonas aeruginosa, Escherichia coli) were distributed. Before inserting the extract impregnated paper disks on the surfaces, the agar plates inoculated with test organism were incubated for 1 hour. For antimicrobial activity testing, three sterile papers blank disks of $6 \mathrm{~mm}$ diameter were mounted on the surface of an agar tray, which was inoculated with indicator strains of $1015 \mu \mathrm{L}$ of filtered supernatant and Lactobacilli pellets. The plates were incubated at $37^{\circ} \mathrm{C}$ for 24 hours after being held at $4^{\circ} \mathrm{C}$ for 30 minutes to allow diffusion on the assay content. Calliper was used to quantify the inhibition zones in millimetres. ${ }^{20}$

\subsection{Resistance to Antibiotic}

Antibiotic behavior of isolates was checked by spreading the fresh overnight cultures thinly on the surface of Rogosa agar plates using sterile cotton swabs. For antibiotic diffusion, antibiotic paper discs were placed on agar plates at $4^{\circ} \mathrm{C}$ for 30 minutes. Streptomycin and gentamycin antibiotic disks were included. Control discs were dipped in distilled water. After that, the plates were anaerobically incubated for 24 hours at $37^{\circ} \mathrm{C}$. The width of the region of inhibition was measured, as well as the diameter of the disks. ${ }^{20}$

\section{RESULTS}

\subsection{Isolation of Lactic Acid Bacteria (LAB)}

The 6 extracted curd samples yielded a total of 8 lactic acid bacteria. These curd samples came from a variety of animal and commercial sources. LAB isolates were labeled A, B, C, D, E, F, G, and H based on physiological and biochemical characteristics.

\subsection{Gram Staining and Motility of Isolates}

Under an electronic microscope with magnifications of $10 x, 50 x$, and $100 x$, the gram staining technique was performed and observed for the presence of different isolates. Many of the isolates were gram-positive and found to be nonmotile (Fig. 1). 


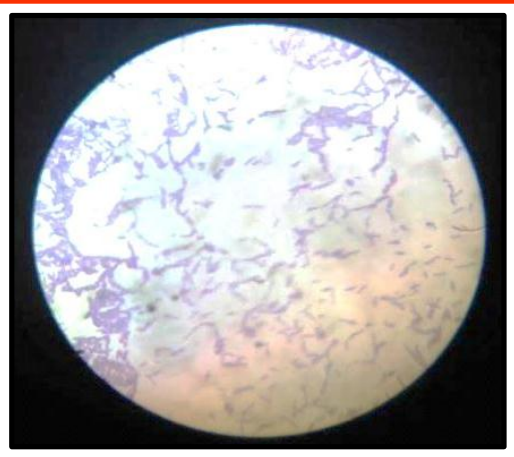

Fig. 1: Gram staining of isolated LAB species

\subsection{Physiological and Biochemical Characterization of Isolates}

All studied isolates were grown at 37 and $45^{\circ} \mathrm{C}$, while isolates from $\mathrm{D}, \mathrm{E}$, and $\mathrm{F}$ were grown at $15^{\circ} \mathrm{C}$, according to biochemical characterization. All of the isolates tested produced no ammonia from arginine and no gas from glucose. The findings of carbohydrate fermentation experiments were used to identify lactobacillus strains. Table 1 lists the products of carbohydrate fermentation. The isolates were identified as Lactobacillus lactis, Lactobacillus fermentum, Lactobacillus leichmannii, Lactobacillus rhamnosus, Lactobacillus casei, Lactobacillus delbrueckii, Lactobacillus brevis and Lactobacillus acidophilus. All isolates tolerated $\mathrm{NaCI}$ concentrations of 2,4 , and 6.5 percent and were found to be catalase negative.

\subsection{Resistance to Low $\mathrm{pH}$}

Five isolates were shown to be $\mathrm{pH} 3$ tolerant in the current study. Lactobacillus rhamnosus has shown tremendous $\mathrm{pH}$ tolerance. The isolates that survived at $\mathrm{pH} 3.0$ were sent on to the next stage of testing. Table 2 shows the results.

\subsection{Resistance to Bile Salt}

According to the findings, all of the isolates were resistant to a concentration of 0.3 percent bile salts, with Lactobacillus delbrueckii being much more resistant than the others. Table 2 shows the results.

\subsection{Antimicrobial Activity}

Three pathogenic strains were tested and all of the isolates showed antimicrobial activity. The zone of inhibitions' diameters was calculated (Table 3). The Lactobacillus delbrueckii strain has a strong inhibition zone.

\subsection{Antimicrobial Activity}

Except for Lactobacillus rhamnosus, all of the isolates have demonstrated antibiotic resistance to ciprofloxacin, streptomycin, and gentamycin. It was determined to measure the inhibition zone (Table 3).

\section{DISCUSSION}

Researchers have been attempting to replace toxic medicines with natural products for a long time. To prevent or cure infections, different natural materials and technologies are now being used. One of these techniques is the use of probiotics. ${ }^{21}$ Lactobacilli and bifidobacteria are natural intestinal flora that perform an important role in the health by avoiding intestinal infection, decreasing cholesterol, stimulating the immune system, and lowering the risk of colon cancer. Probiotic bacteria develop lactic acid and organic acids, lower the $\mathrm{pH}$ of the atmosphere, and attempt to keep many bacteria from growing. ${ }^{22}$

Table 1: Fermentation products and identification of isolated species of LAB

\begin{tabular}{cll}
\hline Isolate & Fermented Products & Species \\
\hline A & Lactose, sucrose, salicine & Lactobacillus lactis \\
\hline B & Mellibiose, sucrose, raffinose and gluconate & Lactobacillus fermentum \\
\hline C & Cellobiose, lactose, sucrose and salicine & Lactobacillus leichmannii \\
\hline D & Mellibiose, cellobiose, gluconate, salicine and arabinose & Lactobacillus rhamnosus \\
\hline E & Lactose, sucrose, gluconate and salicine & Lactobacillus casei \\
\hline F & Sucrose & Lactobacillus delbrueckii \\
\hline G & Mellibiose, gluconate and arabinose & Lactobacillus brevis \\
\hline H & Cellobiose, lactose, sucrose, salicine & Lactobacillus acidophilus
\end{tabular}


Table 2: Survival of isolates in $\mathrm{pH} 3$ and $0.3 \%$ bile salts

\begin{tabular}{ccccc|ccccc} 
& \multicolumn{4}{c|}{ Survival in pH 3 } & \multicolumn{5}{c}{ Survival in 0.3 \% Bile Salts } \\
\cline { 2 - 10 } Isolate & \multicolumn{3}{c|}{ OD at 620 nm at different Time } & \multicolumn{2}{c}{ OD at $\mathbf{5 6 0} \mathbf{n m}$ at different Time Interval (hour) } \\
& $\mathbf{0}$ & $\mathbf{1}$ & $\mathbf{2}$ & $\mathbf{3}$ & $\mathbf{0}$ & $\mathbf{1}$ & $\mathbf{2}$ & $\mathbf{3}$ & $\mathbf{4}$ \\
\hline A & 0.58 & 0.57 & 0.57 & 0.57 & 0.3 & 0.27 & 0.29 & 0.25 & 0.24 \\
\hline D & 0.31 & 0.32 & 0.30 & 0.30 & 0.7 & 0.65 & 0.59 & 0.57 & 0.55 \\
\hline E & 1.01 & 0.98 & 0.97 & 0.97 & 0.6 & 0.58 & 0.55 & 0.52 & 0.51 \\
\hline F & 0.98 & 1.01 & 0.99 & 0.99 & 0.42 & 0.4 & 0.38 & 0.35 & 0.33 \\
\hline G & 0.71 & 0.69 & 0.69 & 0.68 & 0.35 & 0.34 & 032 & 0.28 & 0.26 \\
\hline
\end{tabular}

Table 3: Antimicrobial and Antibiotic Resistance of Isolates

\begin{tabular}{cccc|ccc} 
& \multicolumn{5}{c}{ Antimicrobial Resistance } \\
\cline { 2 - 7 } Isolate & \multicolumn{5}{c}{ Diameter of Inhibition Zones (mm) } \\
& $\begin{array}{c}\text { Staphylococcus } \\
\text { aureus }\end{array}$ & $\begin{array}{c}\text { Pseudomonas } \\
\text { aeruginosa }\end{array}$ & $\begin{array}{c}\text { Escherichia } \\
\text { coli }\end{array}$ & Ciprofloxacin & Streptomycin & Tetracycline \\
A & 9 & 10 & 8 & $\mathrm{R}$ & $\mathrm{R}$ & 13 \\
\hline D & - & - & 7 & 14 & $\mathrm{R}$ & 22 \\
\hline E & 13 & 12 & 8 & $\mathrm{R}$ & $\mathrm{R}$ & $\mathrm{R}$ \\
\hline F & 10 & 8 & 11 & $\mathrm{R}$ & $\mathrm{R}$ & $\mathrm{R}$ \\
\hline G & 7 & - & 8 & $\mathrm{R}$ & $\mathrm{R}$ & $\mathrm{R}$ \\
\hline
\end{tabular}

Boris et al. (2001) discovered that lactobacilli strains derived from dairy products would prevent the development of $P$. aeruginosa, E. coli, and Salmonella typhimurium, which had the most inhibitory effect. ${ }^{23}$

Different probiotic LAB can be identified using a variety of techniques. The following experiments were used in this investigation: carbohydrate fermentation, gas generation from glucose, arginine hydrolysis, development at various temperatures, and acid and bile salt tolerance.

Guessas and Kihal (2004) isolated lactic acid bacteria from goat milk in the Algerian arid region, reporting that all isolates were gram positive, catalase negative, and non-spore forming. ${ }^{24}$ In the current research, eight different lactic acid forming bacteria were isolated from various curd samples. All of the strains were gram positive, non-spore producing, and catalase negative in just a handful of them.

Lactic acid bacteria, according to Zourari et al. (1992), are facultative anaerobes that favor anaerobic environments. Since they are unable to synthesize porphyrins, they are unable to produce cytochromes or catalase. Oxygen is often used to make hydrogen peroxide, which is poisonous to lactic acid bacteria and cannot be broken down by catalase. Catalase is an enzyme used in aerobic species that breaks down hydrogen peroxide in the following way, ${ }^{25}$

$$
2 \mathrm{H}_{2} \mathrm{O}_{2} \rightarrow 2 \mathrm{H}_{2} \mathrm{O}+\mathrm{O}_{2}
$$

Our investigation revealed that the isolates from the Lactobacillus genus lacked the catalase enzyme.

Different strains of lactic acid bacteria were isolated from camel milk by Ahmed and Kanwal (2004). They found that all of the strains were non-motile. ${ }^{26}$ All of the 8 isolates from various curds grew in a confined stab line and were also non-motile.

Forouhanden et al. (2010) isolated lactic acidproducing bacteria from a variety of common and regional cheeses and yoghurts. ${ }^{27}$ Carbon sources were used to assess the biochemical characterizations of all the isolates. Durham's tube was stated to produce acid rather than gas during 
glucose fermentation. During the fermentation of glucose acid, all eight isolates did not produce any gas in the Durham's tube. After a glucose fermentation test, the bacterial cultures were shown to be homo-fermentative.

One of the most important selection criterions for probiotic strains is their resistance to low pH. ${ }^{28}$ They must travel through stressful gastrointestinal conditions to enter the small intestine. All isolates were tested to see if they were immune to $\mathrm{pH} 3.0$ after 3 hours. During 3 hours of incubation, all of the isolates tested were able to survive at $\mathrm{pH}$ 3.0. $\mathrm{pH}$ resistance was higher in Lactobacillus rhamnosus than in other strains.

The strains were tested to see if they could withstand the bile salt. While the bile concentration in the human gastrointestinal tract varies, the average intestinal bile concentration is thought to be 0.3 percent $(\mathrm{w} / \mathrm{v})$ and the stay time to be 4 hours.29 Strains were observed in 0.3 percent of the bile during the 4 hour stay. The results revealed that after four days of exposure, all isolates retained their viability with a negligible reduction in viable counts to a bile concentration of $3 \%(\mathrm{w} / \mathrm{v})$, and that Lactobacillus delbrueckii was more tolerant than the others. Correspondingly, Mulaw et al. (2019) discovered that at 0.3 percent $(\mathrm{w} / \mathrm{v})$ bile salt, all lactic acid bacteria isolated from fermented olive could expand and survive. One of the key factors for in vitro identification of potentially probiotic bacteria and essential points for microbes is their ability to survive in bile salt conditions. ${ }^{30}$

The cell free supernatants of different lactobacillus strains were tested for antimicrobial activity against five pathogenic bacterial strains (Pseudomonas aeruginosa, Staphylococcus aureus, and Escherichia coli) by using disc diffusion method. The antimicrobial activity of cell free supernatants from various lactobacillus strains was examined using the disc diffusion system against three pathogenic bacterial strains (Pseudomonas aeruginosa, Staphylococcus aureus, and Escherichia coli). One of the functional properties used to describe probiotics is the synthesis of antimicrobial compounds such as organic acids, short chain fatty acids, and bactenocins. $^{31}$ The antimicrobial activities of supernatants and cell free supernatants were investigated in this analysis at a concentration of $10 \mu \mathrm{l} /$ disc. The results of the disc diffusion method revealed that the extract had varying degrees of antimicrobial activity against the various strains examined. This is in accordance with Bassyoun et al. (2012), who found that Lactobacillus strains screened against Salmonella thyphimurium, E. coli, and Salmonella typhi were effective. Many of the isolates studied had antibacterial activity toward pathogenic bacteria. $^{32}$

Resistance was determined using antibiotic discs of Ciprofloxacin, Streptomycin, and Tetracycline, as well as the normal disc diffusion process. Calipers were used to measure the inhibition region in millimeters. Lactobacillus casei, Lactobacillus delbrueckii, and Lactobacillus brevis were found to be antibiotic resistant. LAB and lactobacilli have been isolated and characterized from conventional products around the world in recent years, and their antagonistic activity against different pathogens has been tested by many scientists. Lactobacilli and other bacteria, for example, can kill pathogens by a variety of pathways, including competitive exclusion, which results in food safety.

\section{CONCLUSION}

The antagonistic effects of bacteria-produced compounds on a wide variety of microorganisms play a significant role in preserving food and people's health, according to the findings of this research. These bacteria can also be grown to make a variety of foods and pharmaceuticals. They can also be used to make modern dietary supplements as well. As a result, increasing the consumption of probiotic-rich dairy products, as well as identifying and producing foods with the best and most efficient lactobacilli, is encouraged as part of a healthy diet.

Conflict of Interest: None declared.

Source of Support: None. 


\section{REFERENCES}

1. Mishra R, Tandon S, Rathore M, Banerjee M. Antimicrobial Efficacy of Probiotic and Herbal Oral Rinses against Candida albicans in Children: A Randomized Clinical Trial. Int J Clin Pediatr Dent. 2016 Jan-Mar;9(1):25-30.

2. Fijan S, Frauwallner A, Varga L, Langerholc T, Rogelj I, Lorber M, Lewis P, Povalej Bržan P. Health Professionals' Knowledge of Probiotics: An International Survey. Int J Environ Res Public Health. 2019 Aug 28;16(17):3128.

3. Mack DR. Probiotics-mixed messages. Can Fam Physician. 2005 Nov;51(11):1455-7, 1462-4.

4. Markowiak P, Śliżewska K. Effects of Probiotics, Prebiotics, and Synbiotics on Human Health. Nutrients. 2017 Sep 15;9(9):1021.

5. Nazir Y, Hussain SA, Abdul Hamid A, Song Y. Probiotics and Their Potential Preventive and Therapeutic Role for Cancer, High Serum Cholesterol, and Allergic and HIV Diseases. BioMed Research International. Hindawi Limited; 2018 Aug 29;2018:1-17.

6. Mokoena MP. Lactic Acid Bacteria and Their Bacteriocins: Classification, Biosynthesis and Applications against Uropathogens: A MiniReview. Molecules. 2017 Jul 26;22(8):1255.

7. Bintsis $T$. Lactic acid bacteria as starter cultures: An update in their metabolism and genetics. AIMS Microbiol. 2018 Dec 11;4(4):665-684.

8. Terpou A, Papadaki A, Lappa IK, Kachrimanidou V, Bosnea LA, Kopsahelis N. Probiotics in Food Systems: Significance and Emerging Strategies Towards Improved Viability and Delivery of Enhanced Beneficial Value. Nutrients. 2019 Jul 13;11(7):1591.

9. Cencic $A$, Chingwaru $W$. The role of functional foods, nutraceuticals, and food supplements in intestinal health. Nutrients. 2010 Jun;2(6):611-25.

10. Song D, Ibrahim S, Hayek S. Recent Application of Probiotics in Food and Agricultural Science. Probiotics. InTech; 2012.
11. Ren D, Zhu J, Gong S, Liu H, Yu H. Antimicrobial Characteristics of Lactic Acid Bacteria Isolated from Homemade Fermented Foods. BioMed Res Intern. 2018 Dec 30;2018:1-9.

12. Zielińska D, Kolożyn-Krajewska D. Food-Origin Lactic Acid Bacteria May Exhibit Probiotic Properties: Review. Biomed Res Int. 2018 Oct 1;2018:5063185.

13. Menconi A, Kallapura G, Latorre JD, Morgan MJ, Pumford NR, Hargis BM, Tellez G. Identification and characterization of lactic Acid bacteria in a commercial probiotic culture. Biosci Microbiota Food Health. 2014;33(1):25-30.

14. Kozaki M, Uchimura T, Okada S. Experimental manual of lactic acid bacteria. Tokyo, Japan: Asakurasyoten; 1992:34-37.

15. Soltan Dallal MM, Zamaniahari S, Davoodabadi A, Hosseini M, Rajabi Z. Identification and characterization of probiotic lactic acid bacteria isolated from traditional persian pickled vegetables. GMS Hyg Infect Control. 2017 Sep 28;12:Doc15.

16. Marroki A, Zúñiga M, Kihal M, Pérez-Martínez G. Characterization of Lactobacillus from Algerian Goat'S Milk Based on Phenotypic, 16S rDNA Sequencing and their Technological Properties. Braz J Microbiol. 2011 Jan;42(1):158-71.

17. Par H, Peh KK. Characterization and Identification of Lactobacillus Acidophilus Using Biolog Rapid Identification System. Int J Pharm Pharm Sci. 2014;6(1).189193.

18. Tokatlı M, Gülgör G, Bağder Elmacı S, Arslankoz İşleyen N, Özçelik F. In Vitro Properties of Potential Probiotic Indigenous Lactic Acid Bacteria Originating from Traditional Pickles. Biomed Res Int. 2015;2015:315819.

19. Erkkilä S, Petäjä E. Screening of commercial meat starter cultures at low $\mathrm{pH}$ and in the presence of bile salts for potential probiotic use. Meat Sci. 2000 Jul;55(3):297-300. 
20. Hassanzadazar H, Ehsani A, Mardani K, Hesari J. Investigation of antibacterial, acid and bile tolerance properties of lactobacilli isolated from Koozeh cheese. Vet Res Forum. 2012 Summer;3(3):181-5.

21. Pham JV, Yilma MA, Feliz A, Majid MT, Maffetone N, Walker JR, Kim E, Cho HJ, Reynolds JM, Song MC, Park SR, Yoon YJ. A Review of the Microbial Production of Bioactive Natural Products and Biologics. Front Microbiol. Frontiers Media SA; 2019 Jun $20 ; 10$.

22. Nazir Y, Hussain SA, Abdul Hamid A, Song Y. Probiotics and Their Potential Preventive and Therapeutic Role for Cancer, High Serum Cholesterol, and Allergic and HIV Diseases. Biomed Res Int. 2018 Aug 29;2018:3428437.

23. Boris S, Jiménez-Díaz R, Caso JL, Barbés C. Partial characterization of a bacteriocin produced by Lactobacillus delbrueckii subsp. lactis U0004, an intestinal isolate with probiotic potential. J Appl Microbiol. 2001 Aug;91(2):328-33.

24. Guessas, B, Kihal, M. Characterization of lactic acid bacteria isolated from Algerian arid zone raw goats' milk. Afr J Biotechnol. 2004;3:339342.

25. Zourari A, Accolas JP, Desmazeaud HJ. Metabolism and biochemical characteristics of yoghurt bacteria. Lait. 1992;7:21-34.

26. Ahmed T, Kanwal R. Biochemical Characteristics of Lactic Acid Producing Bacteria and Preparation of Camel Milk Cheese by Using Starter Culture. Pakistan Vet J. 2004;24(2):87-91.
27. Forouhandeh H, Vahed ZS, Hejazi MS, Nahaei MR, Dibavar MK. Isolation and Phenotypic Characterization of Lactobacillus species from various dairy products. Current Res Bacteriol. 2010;3:84-88.

28. Shuhadha MF, Panagoda GJ, Madhujith T, Jayawardana NW. Evaluation of probiotic attributes of Lactobacillus sp. isolated from cow and buffalo curd samples collected from Kandy. Ceylon Med J. 2017 Sep 30;62(3):159166.

29. Prete R, Long SL, Gallardo AL, Gahan CG, Corsetti A, Joyce SA. Beneficial bile acid metabolism from Lactobacillus plantarum of food origin. Sci Rep. 2020 Jan 24;10(1):1165.

30. Mulaw G, Sisay Tessema T, Muleta D, Tesfaye A. In Vitro Evaluation of Probiotic Properties of Lactic Acid Bacteria Isolated from Some Traditionally Fermented Ethiopian Food Products. International Journal of Microbiology. Hindawi Limited. 2019 Aug 25;2019:1-11.

31. Markowiak-Kopeć P, Śliżewska K. The Effect of Probiotics on the Production of Short-Chain Fatty Acids by Human Intestinal Microbiome. Nutrients. 2020 Apr 16;12(4):1107.

32. Bassyouni RH, Abdel-all WS, Fadl MG, Abdelall S, kamel Z. Characterization of Lactic Acid Bacteria Isolated from Dairy Products in Egypt as a Probiotic. Life Sci J. 2012;9:2924-2930.

How to Cite the Article: Shirisha K, Priyanka JP, Satya BL. Isolation and Characterization of Probiotics from Different Curd Samples. J Drug Vigil Altern Ther. 2021;1(1):29-36.

\section{www.jdvat.org}

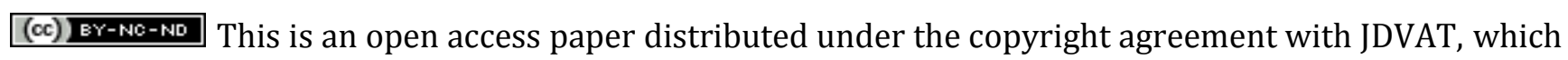
permits non-commercial unrestricted use, distribution, and reproduction in any medium or format, provided the original work is properly cited. 